\title{
Electrochemical destruction of trans-cinnamic acid by advanced oxidation processes: Kinetics, mineralization and \\ degradation route
}

Nelly Flores, Abdoulaye Thiam, Rosa María Rodríguez, Francesc Centellas, Pere

Lluís Cabot, José Antonio Garrido, Enric Brillas*, Ignasi Sirés

Laboratori d'Electroquímica dels Materials i del Medi Ambient, Departament de Química Física, Facultat de Química, Universitat de Barcelona, Martí i Franquès 1-11, 08028 Barcelona, Spain

Article submitted for publication in Environmental Science and Pollution Research

\footnotetext{
* Corresponding author: Tel.: +34 934021223; fax: +34 934021231

E-mail address: brillas@ub.edu (E. Brillas)
} 


\begin{abstract}
Acidic solutions of trans-cinnamic acid at $\mathrm{pH} 3.0$ have been comparatively treated by anodic oxidation with electrogenerated $\mathrm{H}_{2} \mathrm{O}_{2}\left(\mathrm{AO}-\mathrm{H}_{2} \mathrm{O}_{2}\right)$, electro-Fenton (EF) and photoelectroFenton (PEF). The electrolytic experiments were carried out with a boron-doped diamond (BDD)/air-diffusion cell. The substrate was very slowly abated by $\mathrm{AO}-\mathrm{H}_{2} \mathrm{O}_{2}$ because of its low reaction rate with oxidizing ${ }^{\bullet} \mathrm{OH}$ produced from water discharge at the BDD anode. In contrast, its removal was very rapid and at similar rate by $\mathrm{EF}$ and $\mathrm{PEF}$ due to the additional oxidation by ${ }^{\bullet} \mathrm{OH}$ in the bulk, formed from Fenton's reaction between cathodically generated $\mathrm{H}_{2} \mathrm{O}_{2}$ and added $\mathrm{Fe}^{2+}$. The $\mathrm{AO}-\mathrm{H}_{2} \mathrm{O}_{2}$ treatment yielded the lowest mineralization. The EF process led to persistent final products like Fe(III) complexes, which were quickly photolyzed upon UVA irradiation in PEF to give an almost total mineralization with $98 \%$ total organic carbon removal. The effect of current density and substrate concentration on all the mineralization processes was examined. GC-MS analysis of electrolyzed solutions allowed identifying five primary aromatics and one heteroaromatic molecule, whereas final carboxylic acids like fumaric, acetic and oxalic were quantified by ion-exclusion HPLC. From all the products detected, a degradation route for transcinnamic acid is proposed.
\end{abstract}

Keywords: Anodic oxidation; Electro-Fenton; Hydroxyl radical; Oxidation products; PhotoelectroFenton; Photolysis; trans-Cinnamic acid; Water treatment 


\section{Introduction}

trans-Cinnamic acid (E-3-phenyl-2-propenoic acid) is an unsaturated carboxylic acid commonly present in many fruits and vegetables. It is obtained from oil of cinnamon, balsams such as storax and shea butter, and it is synthesized in the industry from the base-catalyzed condensation of acetic anhydride and benzaldehyde or from reaction between cinnamaldehyde and benzal chloride. It is largely used worldwide in fragrances including decorative cosmetics, fine fragrances, shampoos, toilet soaps and other toiletries as well as in non-cosmetic products such as household cleaners and detergents (Letizia et al. 2005). trans-Cinnamic acid has antifungal properties, inhibits the toxicity of metals in plants (Hojati et al. 2015) and acts as an antioxidant with very low toxicity in bacteria, animals and human beings (Letizia et al. 2005; Zeni et al. 2013; Hakkim et al. 2014). It is a main component of toxic and recalcitrant olive oil mill wastewater (OOMWW), where its concentration reaches up to $106 \mathrm{mg} \mathrm{L}^{-1}$ (Deeb et al. 2012), and it has been detected at relatively high contents of $10 \mu \mathrm{g} \mathrm{L}^{-1}$ in rivers (Lafont et al. 2001). Kontos et al. (2014) described the removal and recovery of trans-cinnamic acid from OOMWW by crystallization. Several authors have reported the degradation of this acid and some polyphenolic components of OOMWW using different bacteria strains (Di Gioia et al. 2012) and by several advanced oxidation processes (AOPs) including zero-valent iron (Sanchez et al. 2012) and wet oxidation (Lopes et al. 2007; Lopes and Quinta-Ferreira 2010). AOPs are based on the oxidation of pollutants by in situ generated reactive oxygen species (ROS) like hydroxyl radical $\left(\bullet^{\circ} \mathrm{OH}\right)$. However, much less is known about the treatment of trans-cinnamic acid solutions by powerful electrochemical AOPs (EAOPs). Chatzisymeon et al. (2009) found a very poor mineralization with $25 \%$ chemical oxygen demand (COD) reduction upon anodic oxidation (AO) treatment of $110 \mathrm{~mL}$ of a $5 \mathrm{mM}$ trans-cinnamic acid solution in $0.1 \mathrm{M} \mathrm{HClO}_{4}$ using a Ti//rO ${ }_{2}$ anode after a specific charge consumption of $28 \mathrm{Ah} \mathrm{L}^{-1}$. These authors also describe a similar COD abatement of 30\% for OOMWW with $5 \mathrm{mM} \mathrm{NaCl}$ after consuming $43 \mathrm{Ah} \mathrm{L}^{-1}$. 
$\mathrm{AO}$ is the most popular EAOP and consists in the application of a high current density $(j)$ to the

anode $\mathrm{M}$ of the cell for the direct anodic oxidation of pollutants or, primordially, for their destruction by physisorbed hydroxyl radical $\mathrm{M}\left({ }^{\bullet} \mathrm{OH}\right)$ produced as intermediate of water discharge to $\mathrm{O}_{2}$ at the anode surface (Marselli et al. 2003; Martínez-Huitle and Ferro 2006; Panizza and Cerisola 2009; Brillas and Martínez-Huitle 2015):

$$
\mathrm{M}+\mathrm{H}_{2} \mathrm{O} \rightarrow M\left({ }^{\cdot} \mathrm{OH}\right)+H^{+}+e^{-}
$$

$\mathrm{AO}$ is more effective when a boron-doped diamond (BDD) thin-film electrode is employed as anode. This is due to the higher oxidation ability of physisorbed $\mathrm{BDD}\left({ }^{\bullet} \mathrm{OH}\right)$ generated by reaction (1) compared to that of other physisorbed $\mathrm{M}\left({ }^{\bullet} \mathrm{OH}\right.$ ) produced at anodes like $\mathrm{Pt}$ and $\mathrm{PbO}_{2}$ (Ciríaco et al. 2009; Guinea et al. 2009; Rodrigo et al. 2010; Cavalcanti et al. 2013), as a result of the low interaction BDD- ${ }^{\circ} \mathrm{OH}$ and the larger $\mathrm{O}_{2}$-overpotential of $\mathrm{BDD}$ that favors the reaction of ${ }^{\bullet} \mathrm{OH}$ with organics (Panizza and Cerisola 2009).

The oxidation ability of AO with a BDD anode can be enhanced in an undivided cell by electrogenerating $\mathrm{H}_{2} \mathrm{O}_{2}$ at the cathode from the two-electron reduction of $\mathrm{O}_{2}$ gas via reaction (2). The so-called $\mathrm{AO}-\mathrm{H}_{2} \mathrm{O}_{2}$ process involves the destruction of organics preferentially by physisorbed $\mathrm{BDD}\left({ }^{\circ} \mathrm{OH}\right)$, with only a minor participation of ROS like $\mathrm{H}_{2} \mathrm{O}_{2}$ and its anodic oxidation product $\mathrm{HO}_{2}{ }^{\bullet}$ (Sirés and Brillas 2012; Sirés et al. 2014). Carbon nanotubes (Khataee et al. 2013, 2014), graphite felt (Vatanpour et al. 2009), activated carbon fiber (Wang et al. 2008), carbon modified with metals or metal oxide nanoparticles (Assumpção et al. 2013), carbon felt (Dirany et al. 2012; El-Ghenymy et al. 2014; Yahya et al. 2014), carbon-polytetrafluoroethylene (PTFE) $\mathrm{O}_{2}$ or airdiffusion (Borràs et al. 2010; Thiam et al. 2014, 2015b) and BDD (Cruz-González et al. 2010, 2012) are considered the most suitable carbonaceous cathodes to electrogenerate $\mathrm{H}_{2} \mathrm{O}_{2}$.

$$
\mathrm{O}_{2(g)}+2 \mathrm{H}^{+}+2 e^{-} \rightarrow \mathrm{H}_{2} \mathrm{O}_{2}
$$


The performance of AO- $\mathrm{H}_{2} \mathrm{O}_{2}$ can be improved by means of EAOPs based on Fenton's reaction chemistry like electro-Fenton (EF) and photoelectro-Fenton (PEF), which have recently gained increasing interest for wastewater remediation (Sirés and Brillas 2012: Sirés et al. 2014; Vasudevan and Oturan 2014; Brillas and Martínez-Huitle 2015). In the EF process, a small quantity of $\mathrm{Fe}^{2+}$ is added to the solution to react with $\mathrm{H}_{2} \mathrm{O}_{2}$ via Fenton's reaction (3) yielding $\mathrm{Fe}^{3+}$ and ${ }^{\bullet} \mathrm{OH}$ in the bulk (Dirany et al. 2012; El-Ghenymy et al. 2014; Thiam et al. 2014, 2015a). Organics are then destroyed by both radicals, $\mathrm{M}\left({ }^{\bullet} \mathrm{OH}\right)$ and ${ }^{\bullet} \mathrm{OH}$, at an optimum $\mathrm{pH} \sim 3$. When the PEF process is applied, the treated solution is irradiated with artificial UVA light that causes the photoreduction of $\mathrm{Fe}(\mathrm{OH})^{2+}$ species to $\mathrm{Fe}^{2+}$ and ${ }^{\bullet} \mathrm{OH}$ generation via reaction (4), along with the photodecarboxylation of complexes of Fe(III) with generated carboxylic acids from reaction (5) (Ruiz et al. 2011; Moreira et al. 2013; Florenza et al. 2014; Thiam et al. 2015a).

$$
\begin{aligned}
& \mathrm{H}_{2} \mathrm{O}_{2}+\mathrm{Fe}^{2+} \rightarrow \mathrm{Fe}^{3+}+\mathrm{OH}^{+} \mathrm{OH}^{-} \\
& \mathrm{Fe}(\mathrm{OH})^{2+}+h v \rightarrow \mathrm{Fe}^{2+}+\cdot \mathrm{OH} \\
& \mathrm{Fe}(\mathrm{OOCR})^{2+}+\mathrm{hv} \rightarrow \mathrm{Fe}^{2+}+\mathrm{CO}_{2}+\mathrm{R}^{\cdot}
\end{aligned}
$$

In this paper, we present a comparative study on the degradation of trans-cinnamic acid solutions of $\mathrm{pH} 3.0$ by AO- $\mathrm{H}_{2} \mathrm{O}_{2}$, EF and PEF using a stirred BDD/air-diffusion cell. The influence of $j$ and substrate content on the performance of these EAOPs was examined to clarify the role of generated hydroxyl radicals and UV light. The abatement of trans-cinnamic acid and the evolution of final carboxylic acids were followed by high-performance liquid chromatography (HPLC). Gas chromatography-mass spectrometry (GC-MS) allowed the identification of the primary aromatic intermediates. A plausible route for trans-cinnamic acid mineralization including all detected products is proposed. 


\section{Experimental details}

Chemicals

Analytical grade trans-cinnamic acid (purity > 99\%) was supplied by Sigma-Aldrich and used as received. Acetic, fumaric and oxalic acids were of analytical grade purchased from Panreac. Heptahydrated Fe(II) sulfate and anhydrous sodium sulfate were of analytical grade supplied by Fluka. Analytical grade sulfuric acid was purchased from Merck and used to adjust the initial solution $\mathrm{pH}$ to 3.0. The solutions were prepared with ultrapure water provided by a Millipore MilliQ system (resistivity $>18.2 \mathrm{M} \Omega \mathrm{cm}$ at $25^{\circ} \mathrm{C}$ ). Other chemicals were of HPLC or analytical grade supplied by Avocado, Fluka and Merck.

Electrolytic system

The electrolytic assays were carried out in an open and undivided cylindrical glass cell of 150 $\mathrm{mL}$ capacity equipped with a double jacket for recirculating water through a Thermo Electron Corporation HAAKE DC 10 thermostat. All the experiments were made at $25{ }^{\circ} \mathrm{C}$ and under vigorous stirring with a magnetic bar at $700 \mathrm{rpm}$ to ensure the solution mixing and the transport of reactants toward/from the electrodes. A $3 \mathrm{~cm}^{2}$ BDD thin-film electrode from NeoCoat (La-Chauxde-Fonds, Switzerland) was used as the anode and a $3 \mathrm{~cm}^{2}$ carbon-PTFE air-diffusion cathode from E-TEK (Somerset, NJ, USA) was used as the cathode. The air-diffusion cathode was mounted as described elsewhere (Boye et al. 2003) and was fed with air pumped at $300 \mathrm{~mL} \mathrm{~min}^{-1}$ for $\mathrm{H}_{2} \mathrm{O}_{2}$ generation. The interelectrode gap was about $1 \mathrm{~cm}$. The trials were performed at constant $j$ provided by an EG\&G Princeton Applied Research 273A potentiostat-galvanostat.

Comparative treatment of $100 \mathrm{~mL}$ of solutions with trans-cinnamic acid and $0.05 \mathrm{M} \mathrm{Na}_{2} \mathrm{SO}_{4}$ as background electrolyte at $\mathrm{pH} 3.0$ was carried out by $\mathrm{AO}-\mathrm{H}_{2} \mathrm{O}_{2}$, EF and PEF. Electrolyses for the two latter EAOPs were run after addition of $0.50 \mathrm{mM} \mathrm{Fe} \mathrm{F}^{2+}$ as catalyst since this content was found optimal for many organics treated under similar conditions (Ruiz et al. 2011; Moreira et al. 2013; 
Florenza et al. 2014; Thiam et al. 2015a). For PEF, a Philips TL/6W/08 fluorescent black light blue tube was placed at $8 \mathrm{~cm}$ above the solution. This UVA lamp emitted at $\lambda_{\max }=360 \mathrm{~nm}$ and with $5 \mathrm{~W}$ $\mathrm{m}^{-2}$ average power density, as determined with a Kipp\&Zonen CUV 5 UV radiometer.

Instruments and analytical procedures

A Crison GLP $22 \mathrm{pH}-$ meter was used to measure the solution $\mathrm{pH}$. Total organic carbon (TOC) was determined with a Shimadzu VCSN TOC analyzer. This analysis was performed by filtering the samples withdrawn from treated solutions at regular times with Whatman $0.45 \mu \mathrm{m}$ PTFE filters and, subsequently, directly injecting $50 \mu \mathrm{L}$ aliquots into the above analyzer. Reproducible TOC values with $\pm 1 \%$ accuracy were always determined.

Since the total conversion of trans-cinnamic acid into $\mathrm{CO}_{2}$ can be written as follows:

$$
\mathrm{C}_{9} \mathrm{H}_{8} \mathrm{O}_{2}+16 \mathrm{H}_{2} \mathrm{O} \rightarrow 9 \mathrm{CO}_{2}+40 \mathrm{H}^{+}+40 e^{-}
$$

the mineralization current efficiency (MCE) for each trial was then estimated from Eq. (7) (Ruiz et al. 2011):

$$
\operatorname{MCE}(\%)=\frac{n F V \Delta(T O C)_{\text {exp }}}{4.32 \times 10^{7} \mathrm{mIt}} \times 100
$$

where $n$ is the number of electrons for total mineralization $\left(40 \mathrm{e}^{-}\right.$from reaction $\left.(6)\right), F$ is the Faraday constant $\left(96,487 \mathrm{C} \mathrm{mol}^{-1}\right), V$ is the solution volume (in L), $\Delta$ (TOC) $\exp$ is the experimental TOC abatement (in $\left.\mathrm{mg} \mathrm{L}^{-1}\right), 4.32 \times 10^{7}$ is a conversion factor $\left(3,600 \mathrm{~s} \mathrm{~h}^{-1} \times 12,000\right.$ $\left.\mathrm{mg} \mathrm{C} \mathrm{mol}{ }^{-1}\right), m$ is the number of carbon atoms of trans-cinnamic acid ( $9 \mathrm{C}$ atoms), $I$ is the current (in A) and $t$ is the electrolysis time (in $\mathrm{h}$ ).

Reversed-phase HPLC was used to follow the kinetic decay of trans-cinnamic acid. These measurements were made by injecting $10 \mu \mathrm{L}$ aliquots into a Waters $600 \mathrm{LC}$ containing a BDS Hypersil C18 $6 \mu \mathrm{m}, 250 \mathrm{~mm} \times 4.6 \mathrm{~mm}$, column at $35^{\circ} \mathrm{C}$, coupled to a Waters 996 photodiode array detector selected at $\lambda=276 \mathrm{~nm}$. All the samples were filtered with Whatman $0.45 \mu \mathrm{m}$ 
PTFE filters, although for the EF and PEF assays, they were previously diluted with acetonitrile

(1:1) to stop the degradation process. The mobile phase was an 80:20 (v/v) acetonitrile/water mixture eluted at $0.8 \mathrm{~mL} \mathrm{~min}^{-1}$ and the chromatograms exhibited a well-defined peak for transcinnamic acid at retention time $\left(t_{\mathrm{r}}\right)=3.45 \mathrm{~min}$.

The same LC system was used to detect and quantify the generated carboxylic acids by ionexclusion HPLC, but with a Bio-Rad Aminex HPX 87H, $300 \mathrm{~mm} \times 7.8 \mathrm{~mm}$, column at $35^{\circ} \mathrm{C}$ and the photodiode array detector set at $\lambda=210 \mathrm{~nm}$. This analysis was also performed with 10 $\mu \mathrm{L}$ aliquots, circulating $4 \mathrm{mM} \mathrm{H} \mathrm{H}_{2} \mathrm{SO}_{4}$ at $0.6 \mathrm{~mL} \mathrm{~min}^{-1}$ as mobile phase. The chromatograms recorded displayed peaks associated to oxalic $\left(t_{\mathrm{r}}=6.9 \mathrm{~min}\right)$, acetic $\left(t_{\mathrm{r}}=14.9 \mathrm{~min}\right)$ and fumaric $\left(t_{\mathrm{r}}=15.6 \mathrm{~min}\right)$ acids.

The primary aromatic products of trans-cinnamic acid were identified from the AO- $\mathrm{H}_{2} \mathrm{O}_{2}$ treatment of $100 \mathrm{~mL}$ of a $0.926 \mathrm{mM}$ substrate solution at $33.3 \mathrm{~mA} \mathrm{~cm}^{-2}$. Various electrolyses were run up to 30 and 90 min and the remaining organic components of each solution were extracted out with $\mathrm{CH}_{2} \mathrm{Cl}_{2}(3 \times 25 \mathrm{~mL})$. The resulting organic fractions were dried over anhydrous $\mathrm{Na}_{2} \mathrm{SO}_{4}$, filtered and their volume reduced to near $1 \mathrm{~mL}$ for further analysis by GC-MS using a NIST05-MS library to elucidate the mass spectra. GC-MS measurements were performed with an Agilent Technologies system composed of a 6890N GC and a 5975C MS operating in electron impact mode at $70 \mathrm{eV}$. The $\mathrm{GC}$ was fitted with either a non-polar Agilent J\&W HP-5ms or a polar HP INNOWax column, both of $0.25 \mu \mathrm{m}, 30 \mathrm{~m} \times 0.25 \mathrm{~mm}$. The temperature ramp was: $36^{\circ} \mathrm{C}$ for $1 \mathrm{~min}, 5^{\circ} \mathrm{C} \min ^{-1}$ up to $300{ }^{\circ} \mathrm{C}$ for the non-polar column or $250{ }^{\circ} \mathrm{C}$ for the polar one, and hold time $10 \mathrm{~min}$. The temperature of the inlet, source and transfer line was 250,230 and $280{ }^{\circ} \mathrm{C}$ for the non-polar column and 250,230 and $250^{\circ} \mathrm{C}$ for the polar one. 


\section{Results and discussion}

Kinetic decay of trans-cinnamic acid by $\mathrm{AO}-\mathrm{H}_{2} \mathrm{O}_{2}, \mathrm{EF}$ and $\mathrm{PEF}$

The decay kinetics of trans-cinnamic acid by the different EAOPs using a BDD/air-diffusion cell was first determined for $100 \mathrm{~mL}$ of $0.926 \mathrm{mM}$ substrate solutions in $0.05 \mathrm{M} \mathrm{Na}_{2} \mathrm{SO}_{4}$ of pH 3.0 at $33.3 \mathrm{~mA} \mathrm{~cm}{ }^{-2}$. In AO- $\mathrm{H}_{2} \mathrm{O}_{2}$ (no catalyst) as well as in $\mathrm{EF}$ and $\mathrm{PEF}\left(0.50 \mathrm{mM} \mathrm{Fe} e^{2+}\right.$ as catalyst), the solution $\mathrm{pH}$ underwent a slight fall from 3.0 to $~ 2.7-2.8$ after $360 \mathrm{~min}$ of electrolysis, which can be ascribed to the production of acidic products such as carboxylic acids (Ruiz et al. 2011; Moreira et al. 2013; Florenza et al. 2014; Thiam et al. 2015a). A preliminary study with the same solution under a $6 \mathrm{~W}$ UVA irradiation in the absence of electric current confirmed that the substrate content did not vary with time, as expected if trans-cinnamic acid is not directly photolyzed by UVA light.

Fig. 1a depicts a very slow abatement of trans-cinnamic acid by $\mathrm{AO}-\mathrm{H}_{2} \mathrm{O}_{2}$, requiring $360 \mathrm{~min}$ to completely disappear. The reaction rate of this compound with generated ROS, pre-eminently with $\mathrm{BDD}\left({ }^{\circ} \mathrm{OH}\right)$ originated from reaction (1), is then very low. In contrast, Fig. 1b depicts a much quicker decay and at similar rate in EF and PEF, being completely removed in about $42 \mathrm{~min}$ in both cases. The more rapid disappearance of this compound in such processes can be related to its faster reaction occurring in the bulk with ${ }^{\bullet} \mathrm{OH}$ originated from Fenton's reaction (3) compared with the much slower attack of $\mathrm{BDD}\left({ }^{\circ} \mathrm{OH}\right)$ confined near the anode. The quite similar removal rate in $\mathrm{EF}$ and PEF can be explained by a very small contribution of the photolytic reaction (4) to produce greater quantities of ${ }^{\circ} \mathrm{OH}$ in the bulk.

The concentration decays of Figs. 1a and b were well fitted to a pseudo-first-order kinetic equation, as can be seen in the inset panels. This behavior suggests that trans-cinnamic acid is attacked by a steady concentration of $\mathrm{BDD}\left({ }^{\bullet} \mathrm{OH}\right)$ and/or ${ }^{\bullet} \mathrm{OH}$ in each treatment. From this analysis, apparent rate constants $\left(k_{1}\right)$ of $0.012 \mathrm{~min}^{-1}$ (square regression coefficient $R^{2}=0.991$ ) for $\mathrm{AO}-\mathrm{H}_{2} \mathrm{O}_{2}$, $0.052 \mathrm{~min}^{-1}\left(R^{2}=0.998\right)$ for $\mathrm{EF}$ and $0.050 \mathrm{~min}^{-1}\left(R^{2}=0.9990\right)$ for PEF were obtained. The $k_{1}$ value 
in EF and PEF was 4.2-4.3 orders of magnitude greater than that in $\mathrm{AO}-\mathrm{H}_{2} \mathrm{O}_{2}$, corroborating the much larger oxidation ability of ${ }^{\bullet} \mathrm{OH}$ compared to $\mathrm{BDD}\left({ }^{\bullet} \mathrm{OH}\right)$ in the two former EAOPs.

The study of the kinetic decay of trans-cinnamic acid was extended to lower concentrations of 0.185 and $0.463 \mathrm{mM}$ by applying $33.3 \mathrm{~mA} \mathrm{~cm}^{-2}$. Total removal of the substrate occurred at shorter time as the initial organic load decreased. For example, in $\mathrm{AO}-\mathrm{H}_{2} \mathrm{O}_{2}$, trans-cinnamic acid disappeared at 270, 330 and $360 \mathrm{~min}$ for $0.185,0.463$ and $0.926 \mathrm{mM}$, respectively, whereas its removal in the EF treatment occurred at 8,20 and $42 \mathrm{~min}$ for the same concentrations. According to this trend, a raising $k_{1}$ value with decreasing substrate content was obtained from the corresponding pseudo-first-order kinetic analysis. Thus, $k_{1}$ grew from $0.012 \mathrm{~min}^{-1}\left(R^{2}=0.991\right)$ to $0.014 \mathrm{~min}^{-1}\left(R^{2}=\right.$ 0.992) in $\mathrm{AO}-\mathrm{H}_{2} \mathrm{O}_{2}$ and from $0.052 \mathrm{~min}^{-1}\left(R^{2}=0.998\right)$ to $0.58 \mathrm{~min}^{-1}\left(R^{2}=0.994\right)$ in $\mathrm{EF}$ when changing from $0.926 \mathrm{mM}$ to $0.185 \mathrm{mM}$. It is then evident that the kinetic decay of this acid does not obey a true pseudo-first-order reaction, because similar $k_{1}$ values should be found independently of its initial content. Since analogous quantities of $\mathrm{BDD}\left({ }^{\bullet} \mathrm{OH}\right)$ and/or ${ }^{\bullet} \mathrm{OH}$ are produced in each EAOP at $j=33.3 \mathrm{~mA} \mathrm{~cm}^{-2}$ as the organic load grows, a larger proportion of these oxidizing radicals is able to react with the oxidation products generated, thus decreasing their available quantity to attack the trans-cinnamic acid, eventually decelerating its removal.

\subsection{Mineralization of trans-cinnamic acid solutions by $\mathrm{AO}-\mathrm{H}_{2} \mathrm{O}_{2}, \mathrm{EF}$ and $\mathrm{PEF}$}

For the above solutions with $0.926 \mathrm{mM}$ trans-cinnamic acid of $\mathrm{pH} 3.0$ treated by the EAOPs at $33.3 \mathrm{~mA} \mathrm{~cm}^{-2}$, their TOC decay was determined in order to ascertain the relative mineralization ability. Fig. 2a highlights a slow and continuous TOC removal under $\mathrm{AO}-\mathrm{H}_{2} \mathrm{O}_{2}$ conditions, reaching a partial mineralization of $68 \%$ after 360 min of electrolysis. A much rapid TOC abatement can be observed in EF, with a final TOC reduction of $78 \%$. It should be noted that the mineralization process in EF was very fast up to $120 \mathrm{~min}$ as a result of the efficient oxidation by ${ }^{\bullet} \mathrm{OH}$ but, at longer time, it underwent a progressive deceleration suggesting the generation of more recalcitrant products, like $\mathrm{Fe}(\mathrm{III})$-carboxylate complexes, which are very refractory to ${ }^{\circ} \mathrm{OH}$ and can only be 
slowly destroyed by $\operatorname{BDD}\left({ }^{\circ} \mathrm{OH}\right)$ (Sirés et al. 2014). Fig. 2a also evidences a very positive effect of UVA irradiation during the PEF process, which yielded a high TOC decay rate to attain an almost total mineralization with $98 \%$ TOC reduction at $360 \mathrm{~min}$. This large acceleration of the mineralization process can be ascribed to the photolysis of products such as $\mathrm{Fe}(\mathrm{III})$-carboxylate species via reaction (5) (Sirés et al. 2014; Brillas and Martínez-Huitle 2015). These findings indicate that the oxidation ability of the EAOPs to mineralize the trans-cinnamic acid increases in the sequence $\mathrm{AO}-\mathrm{H}_{2} \mathrm{O}_{2}<\mathrm{EF}<\mathrm{PEF}$.

Fig. 2b shows the MCE values estimated from Eq. (7) for the assays of Fig. 2a. A higher current efficiency was obtained as the relative mineralization power of the EAOP increased. This tendency was more apparent between 60 and $120 \mathrm{~min}$ of electrolysis, because of the effect of $\mathrm{BDD}\left({ }^{\bullet} \mathrm{OH}\right)$ and ${ }^{\bullet} \mathrm{OH}$ oxidation and photolysis on the mineralization rate in each treatment. In PEF, the MCE value dropped from $71 \%$ at the beginning of the treatment to $16 \%$ at $360 \mathrm{~min}$. This fall in current efficiency can be explained by the production of more recalcitrant final oxidation products as well as the progressive loss of organic matter (Panizza and Cerisola 2009; Florenza et al. 2014; Thiam et al. 2015b). In the case of EF, the MCE value rose from an initial $14 \%$ to $28 \%$ at 120 min, further decaying to $13 \%$. This is due to the initial formation of some persistent products that react slowly with ${ }^{\bullet} \mathrm{OH}$ in $\mathrm{EF}$, requiring longer time for their mineralization, whereas their continuous removal caused the increase in MCE at the beginning of this process. In contrast, the MCE values in AO- $\mathrm{H}_{2} \mathrm{O}_{2}$ remained practically constant between $13 \%$ and $15 \%$, indicating a constant mineralization rate of products upon $\operatorname{BDD}\left({ }^{\bullet} \mathrm{OH}\right)$ oxidation.

Effect of applied current density and substrate concentration on the performance of EAOPs

It is well known that the amount of oxidizing hydroxyl radicals acting in each EAOP is limited by the applied $j$. To clarify the influence of this key operation parameter, the mineralization of $0.926 \mathrm{mM}$ trans-cinnamic acid solutions was carried out at $j$ in the range $16.7-100 \mathrm{~mA} \mathrm{~cm}{ }^{-2}$. Figs. 
3a-c depict the TOC decay vs. electrolysis time measured in the AO- $\mathrm{H}_{2} \mathrm{O}_{2}, \mathrm{EF}$ and PEF assays, respectively. For the former process, Fig. 3a shows a quite similar TOC abatement at $16.7-66.7$ $\mathrm{mA} \mathrm{cm}^{-2}$ during about $240 \mathrm{~min}$, whereas the mineralization rate increased more significantly at 100 $\mathrm{mA} \mathrm{cm}{ }^{-2}$. This means that the expected rise in $\operatorname{BDD}\left({ }^{\bullet} \mathrm{OH}\right)$ from the acceleration of reaction (1) at higher $j$ (Sirés et al. 2014) has little influence on the destruction of organics, indicating that the excess of ROS produced are rather consumed in parasitic reactions, as will be discussed below. The influence of $j$ in $\mathrm{AO}-\mathrm{H}_{2} \mathrm{O}_{2}$ was more apparent between 240 and $360 \mathrm{~min}$, when final products like short-linear carboxylic acids are the main accumulated organics. At $360 \mathrm{~min}$, for example, increasing TOC reductions of $64 \%, 68 \%, 76 \%$ and $84 \%$ for $16.7,33.3,66.7$ and $100 \mathrm{~mA} \mathrm{~cm}^{-2}$, respectively, were found. A partial mineralization but with greater TOC decay can be seen in Fig. $3 \mathrm{~b}$ for the comparative EF runs. In this process, higher $j$ originated more quantities of $\mathrm{BDD}\left({ }^{\bullet} \mathrm{OH}\right)$ as well as greater amounts of ${ }^{\bullet} \mathrm{OH}$ in the bulk due to the quicker generation of $\mathrm{H}_{2} \mathrm{O}_{2}$ by reaction (2) and the concomitant acceleration of Fenton's reaction (3). Both ROS then play a pre-eminent role to destroy the intermediates and their Fe(III) complexes and thus, greater TOC decay at higher $j$ values can be clearly distinguished in Fig. $3 \mathrm{~b}$ from 120 min of electrolysis. At the end of these treatments, however, the best $j$ of $100 \mathrm{~mA} \mathrm{~cm} \mathrm{~cm}^{-2}$ only yielded $90 \%$ mineralization. The behavior was very different when PEF was applied. Fig. 3c reveals that the low production of $\mathrm{BDD}\left({ }^{\bullet} \mathrm{OH}\right)$ and ${ }^{\bullet} \mathrm{OH}$ at $16.7 \mathrm{~mA} \mathrm{~cm}^{-2}$ impeded the complete production of photosensitive products and, therefore, only $91 \%$ TOC reduction was achieved at $360 \mathrm{~min}$. In contrast, the use of $j \geq 33.3 \mathrm{~mA} \mathrm{~cm} \mathrm{~cm}^{-2}$ favored an effective generation of oxidants, and nearly all the accumulated products were photosensitive and were removed at similar rate yielding an almost total mineralization with 97-98\% TOC reduction at the end of all the treatments. These findings indicate that $33.3 \mathrm{~mA} \mathrm{~cm}{ }^{-2}$ can be considered as the best $j$ value for the application of this EAOP to degrade a $0.926 \mathrm{mM}$ trans-cinnamic solution.

Figs. 4a-c show a loss in current efficiency for each EAOP as $j$ rose. This tendency is not surprising in view of the low effect of this parameter on the TOC decay of all the treatments, mainly 
in $\mathrm{AO}-\mathrm{H}_{2} \mathrm{O}_{2}$ and PEF (see Figs. 3a and c). As shown in Fig. 4a, the MCE values in each $\mathrm{AO}-\mathrm{H}_{2} \mathrm{O}_{2}$ at a given $j \geq 33.3 \mathrm{~mA} \mathrm{~cm} \mathrm{~cm}^{-2}$ basically remained unchanged during each run, as expected for a constant mineralization rate of intermediates, whereas at $16.7 \mathrm{~mA} \mathrm{~cm}{ }^{-2}$, it gradually dropped from $39 \%$ to $21 \%$ due to the smaller mineralization ability of the lower amounts of $\operatorname{BDD}\left({ }^{\circ} \mathrm{OH}\right)$ generated. For EF, a maximum MCE value was attained after 90-120 min of all the assays (see Fig. 4b), corroborating the initial formation of several products that are slowly destroyed by hydroxyl radicals while their gradual mineralization largely improves the current efficiency at the beginning of the process. The same phenomenon is shown in Fig. 4c for PEF at $16.7 \mathrm{~mA} \mathrm{~cm}^{-2}$, since the smaller amounts of $\operatorname{BDD}\left({ }^{\bullet} \mathrm{OH}\right)$ and ${ }^{\bullet} \mathrm{OH}$ produced under these conditions attack slowly the substrate and its products and low quantities of photosensitive species are formed to be removed by UVA light. Current efficiency then grew as these initial recalcitrant products progressively disappeared from the medium. This behavior was not found for greater $j$ values because the mineralization was enhanced by the faster photolysis of larger quantities of products, like Fe(III)carboxylate species. In all the EF and PEF assays, the current efficiency diminished at long electrolysis time due to two main contributions, the loss of organic load and the formation of more recalcitrant intermediates, as stated above. For the most powerful EAOP, i.e., PEF process, maximum MCE of $\sim 71-73 \%$ was obtained after 90 and 30 min at 16.7 and $33.3 \mathrm{~mA} \mathrm{~cm}^{-2}$.

The decay in MCE as $j$ grows is typical of EAOPs and can be associated with the consumption of the excess of generated hydroxyl radicals by waste reactions. For example, the anodic oxidation of physisorbed $\mathrm{BDD}\left({ }^{\bullet} \mathrm{OH}\right)$ to $\mathrm{O}_{2}$ via reaction (8) and the removal of ${ }^{\bullet} \mathrm{OH}$ by $\mathrm{Fe}^{2+}$ and $\mathrm{H}_{2} \mathrm{O}_{2}$ via reactions (9) and (10), respectively (Sirés and Brillas 2012; Sirés et al. 2014). It is also expected that the formation of other weaker oxidants at the BDD anode such as ozone via reaction (11) and $\mathrm{S}_{2} \mathrm{O}_{8}{ }^{2-}$ ion from $\mathrm{SO}_{4}{ }^{2-}$ ion of the electrolyte via reaction (12), thereby inhibiting the $\mathrm{H}_{2} \mathrm{O}$ discharge from reaction (1) (Panizza and Cerisola 2009), become largely enhanced as well.

$$
2 B D D\left({ }^{\circ} O H\right) \rightarrow 2 B D D+O_{2}+2 H^{+}+2 e^{-}
$$




$$
\begin{aligned}
& \mathrm{Fe}^{2+}+\cdot \mathrm{OH} \rightarrow \mathrm{Fe}^{3+}+\mathrm{OH}^{-} \\
& \mathrm{H}_{2} \mathrm{O}_{2}+\cdot \mathrm{OH} \rightarrow \mathrm{HO}_{2}^{\cdot}+\mathrm{H}_{2} \mathrm{O} \\
& 3 \mathrm{H}_{2} \mathrm{O} \rightarrow \mathrm{O}_{3}+6 \mathrm{H}^{+}+6 e^{-} \\
& 2 \mathrm{SO}_{4}^{2-} \rightarrow \mathrm{S}_{2} \mathrm{O}_{8}^{2-}+2 e^{-}
\end{aligned}
$$

Another important operation parameter in the EAOPs is the substrate concentration since it determines the oxidation ability of hydroxyl radicals and/or their combined action with the photooxidation by UVA light. The influence of this parameter was examined for $0.185,0.463,0.926$ and $1.852 \mathrm{mM}$ of trans-cinnamic acid at the best $j=33.3 \mathrm{~mA} \mathrm{~cm}^{-2}$ found for PEF, and the results are presented in Figs. 5a-c. Oscillating final percentages of TOC removal were always found for each EAOP with increasing substrate content. For example, at the end of the above treatments, TOC was reduced by $68-81 \%$ in $\mathrm{AO}-\mathrm{H}_{2} \mathrm{O}_{2}, 75-81 \%$ in $\mathrm{EF}$ and $87-97 \%$ in PEF. Note that quite analogous percentages of TOC abatement were found for the two former treatments up to $0.463 \mathrm{mM}$, thus showing similar final mineralization values.

For the above assays, however, greater amounts of TOC were always removed with raising the organic load of the solution and this fact is reflected in Figs. 6a-c from the concomitant enhancement of the corresponding MCE values. At $120 \mathrm{~min}$, for example, operating between 0.185 and $1.852 \mathrm{mM}$ trans-cinnamic acid, the current efficiency gradually grew from $3.6 \%$ to $38 \%$, from $5.1 \%$ to $53 \%$ and from $8.6 \%$ to $60 \%$ in $\mathrm{AO}-\mathrm{H}_{2} \mathrm{O}_{2}, \mathrm{EF}$ and $\mathrm{PEF}$, respectively. These findings confirm again that the relative oxidation ability of these EAOPs always increased in the sequence AO- $\mathrm{H}_{2} \mathrm{O}_{2}<\mathrm{EF}<\mathrm{PEF}$. As mentioned above, similar quantities of $\mathrm{BDD}\left({ }^{\bullet} \mathrm{OH}\right)$ and/or ${ }^{\bullet} \mathrm{OH}$ are expected to be generated in each EAOP at $33.3 \mathrm{~mA} \mathrm{~cm}^{-2}$. Consequently, one can infer that a larger organic load favors the reaction of higher quantities of these oxidizing species with intermediates, with deceleration of the waste reactions (8)-(12). The quicker formation of products also enhanced the PEF process because the resulting photosensitive species can be more rapidly removed upon 
UVA irradiation. Nevertheless, the most concentrated solution was only mineralized up to a $92 \%$ by

this procedure, a value lower than $98 \%$ obtained for 0.463 and $0.962 \mathrm{mM}$ solutions, where lower amounts of undesired persistent products are finally accumulated. Figs. $6 \mathrm{~b}$ and c highlight again the fall of current efficiency at prolonged electrolysis because of both, the gradual generation of highly recalcitrant products and the loss of organic matter, as pointed out above.

All these findings allow concluding that the most convenient conditions for applying the PEF process involve the treatment of $0.926 \mathrm{mM}$ trans-cinnamic at $33.3 \mathrm{~mA} \mathrm{~cm}{ }^{-2}$, since this yielded the greatest mineralization with $98 \%$ TOC removal and an acceptable current efficiency of $16 \%$ during final stages. Higher current values did not accelerate the process and produced a significant MCE decay. The use of more concentrated solutions is not beneficial because of the lower TOC removal.

Identification of products and evolution of generated carboxylic acids

Table 1 summarizes the characteristics of five primary aromatics and one heteroaromatic product of trans-cinnamic acid (1) identified by GC-MS after 30 and 90 min of $\mathrm{AO}-\mathrm{H}_{2} \mathrm{O}_{2}$ treatment of a $0.926 \mathrm{mM}$ substrate solution at $\mathrm{pH} 3.0$ and $33.3 \mathrm{~mA} \mathrm{~cm}$. While the heteroaromatic 2 arises from an internal cyclization of the carboxylic group of $\mathbf{1}$, the aldehyde $\mathbf{3}$ is produced from its decarboxylation and the acid $\mathbf{4}$ from the oxidation of its double bond to a single one. Further degradation of $\mathbf{3}$ yields compounds 5-7.

It is expected that the cleavage of the benzene ring of the above compounds leads to linear products that evolve to short-linear aliphatic carboxylic acids (El-Ghenymy et al. 2014; Sirés et al. 2014). This possibility was corroborated by ion-exclusion HPLC analysis of the solutions degraded under the conditions of Fig. 2. Fumaric (8), acetic (9) and oxalic (10) acids were detected in these chromatograms allowing the quantification of their concentrations during the electrolysis. Acid $\mathbf{1 0}$ was also identified by GC-MS as a deprotonated ion with $\mathrm{m} / \mathrm{z} 89$ (see Table 1 ). Note that the final acids $\mathbf{8}$ and $\mathbf{9}$ are oxidized to the ultimate acid 10, which is directly converted into $\mathrm{CO}_{2}$ (Ruiz et al. 2011; Sirés and Brillas 2012). These acids form Fe(III) complexes to a large extent in EF and PEF, 
being slowly oxidized by $\operatorname{BDD}\left({ }^{\bullet} \mathrm{OH}\right)$ and more hardly attacked by ${ }^{\bullet} \mathrm{OH}$ (Moreira et al. 2013; Florenza et al. 2014; Thiam et al. 2015a).

Traces of acid $8(<0.0043 \mathrm{mM})$ appeared until $120 \mathrm{~min}$ of all treatments, whereas small contents of acid 9 were only found after 180 min of $\mathrm{AO}-\mathrm{H}_{2} \mathrm{O}_{2}$. These compounds and their $\mathrm{Fe}(\mathrm{III})$ complexes were then rapidly removed by hydroxyl radicals. In contrast, Fig. 7 shows that the final acid 10 was much more largely accumulated in all the EAOPs, then being the main carboxylic acid generated during the mineralization process of trans-cinnamic acid. In $\mathrm{AO}-\mathrm{H}_{2} \mathrm{O}_{2}$, this acid was progressively accumulated up to $0.137 \mathrm{mM}$ as maximal at $180 \mathrm{~min}$, whereupon it decayed to 0.094 $\mathrm{mM}$. This value accounts for $2.3 \mathrm{mg} \mathrm{L}^{-1} \mathrm{TOC}$, only contributing in $7.2 \%$ to the organic load of the remaining solution (32 $\mathrm{mg} \mathrm{L}^{-1} \mathrm{TOC}$, see Fig. 2). This means that the majority of components (93\%) of such solution were recalcitrant products that are slowly destroyed by $\operatorname{BDD}\left({ }^{\bullet} \mathrm{OH}\right)$. On the other hand, Fig. 7 reveals a very high accumulation of acid $\mathbf{1 0}$ up to $0.86 \mathrm{mM}$ at $60 \mathrm{~min}$ in $\mathrm{EF}$ and 1.02 $\mathrm{mM}$ at 40 min in PEF as a result of the much faster destruction of primary intermediates by ${ }^{\bullet} \mathrm{OH}$. At longer time, the evolution of this acid depended on the characteristics of each treatment. In EF, the slow oxidation of $\mathrm{Fe}(\mathrm{III})$-oxalate species mainly by $\mathrm{BDD}\left({ }^{\circ} \mathrm{OH}\right)$ yielded $0.38 \mathrm{mM}$ of $\mathbf{1 0}$, related to $9.1 \mathrm{mg} \mathrm{L}^{-1}$ TOC and a $41 \%$ of the $22 \mathrm{mg} \mathrm{L}^{-1}$ TOC of the final solution (see Fig. 2). The remaining solution of EF then contained 59\% of undetected products that are highly recalcitrant to hydroxyl radicals. Conversely, the UVA irradiation used in PEF led to rapid and total photodecarboxylation of $\mathrm{Fe}(\mathrm{III})$-oxalate complexes via reaction (5), with all the acid $\mathbf{1 0}$ disappearing in only $240 \mathrm{~min}$, although the final solution at 360 min still contained a $2 \%$ of the starting TOC (see Fig. 2). One can infer that the PEF process destroys most of persistent products that cannot be oxidized by hydroxyl radicals in EF, thanks to the photolytic action of UVA light. This behavior along with the total removal of final carboxylic acids justifies the almost total mineralization achieved in PEF. 
Degradation route for trans-cinnamic acid by EAOPs with BDD

Based on the products identified in this work, a plausible route for trans-cinnamic acid mineralization by EAOPs with a BDD anode is proposed in Fig. 8. The oxidation of the substrate and its aromatic and heteroaromatic products occurs by reaction with $\mathrm{BDD}\left({ }^{\bullet} \mathrm{OH}\right)$ in $\mathrm{AO}-\mathrm{H}_{2} \mathrm{O}_{2}$ and more rapidly with ${ }^{\bullet} \mathrm{OH}$ in $\mathrm{EF}$ and PEF. The final carboxylic acids and Fe(III)-carboxylate species are preferentially attacked by $\mathrm{BDD}\left({ }^{\bullet} \mathrm{OH}\right)$. Other generated oxidants like $\mathrm{H}_{2} \mathrm{O}_{2}, \mathrm{HO}_{2}{ }^{\bullet}, \mathrm{O}_{3}$ and $\mathrm{S}_{2} \mathrm{O}_{8}{ }^{2-}$ can oxidize much more slowly some of the products as well. In the proposed path, only the fate of $\mathrm{Fe}(\mathrm{III})$-oxalate complexes is specified for the sake of simplicity.

The route is initiated by the attack of hydroxyl radicals over $\mathbf{1}$ to cause: (i) an internal cyclization of its carboxylic group producing the heteroaromatic 2, (ii) its decarboxylation followed by oxidation to generate the aldehyde 3 and (iii) the transformation of its double bond giving the saturated carboxylic acid 4. Subsequent oxidation of $\mathbf{3}$ yields the saturated acid $\mathbf{5}$ and benzaldehyde 6, which is then oxidized to benzoic acid 7. Further cleavage of the benzene ring of all the above compounds gives a mixture of final acids 8-10. Acids 8 and 9, formed to a small extent, are rapidly converted into acid 10. This acid is transformed into $\mathrm{CO}_{2}$ by $\mathrm{BDD}\left({ }^{\bullet} \mathrm{OH}\right)$ in $\mathrm{AO}-\mathrm{H}_{2} \mathrm{O}_{2}$, whereas in $\mathrm{EF}$ and $\mathrm{PEF}$, it forms $\mathrm{Fe}(\mathrm{III})$-oxalate species that are slowly mineralized by $\mathrm{BDD}\left({ }^{\circ} \mathrm{OH}\right)$ and much more quickly photodecarboxylated by UVA light with $\mathrm{Fe}^{2+}$ regeneration via reaction (5).

\section{Conclusions}

The PEF degradation of $0.926 \mathrm{mM}$ trans-cinnamic acid solutions of $\mathrm{pH} 3.0$ led to an almost total mineralization at $j \geq 33.3 \mathrm{~mA} \mathrm{~cm}^{-2}$. PEF is much more powerful than $\mathrm{EF}$, which yielded $90 \%$ TOC abatement as maximal at $100 \mathrm{~mA} \mathrm{~cm}{ }^{-2}$, because of the quick photodegradation of highly recalcitrant products like $\mathrm{Fe}(\mathrm{III})$-carboxylate complexes. The oxidation power of $\mathrm{AO}-\mathrm{H}_{2} \mathrm{O}_{2}$ was always lower than that of $\mathrm{EF}$, indicating the positive combination of $\mathrm{BDD}\left({ }^{\bullet} \mathrm{OH}\right)$ produced at the anode and $\bullet \mathrm{OH}$ formed from Fenton's reaction to remove organics. For each EAOP, increasing $j$ 
from 16.7 to $100 \mathrm{~mA} \mathrm{~cm}{ }^{-2}$ caused more rapid mineralization with lower current efficiency, whereas the use of more concentrated solutions from 0.185 to $1.852 \mathrm{mM}$ enhanced the amount of TOC abated, which caused a gradual rise of current efficiency at long electrolysis time. Five primary aromatics, one heteroaromatic and three short final carboxylic acids were identified. Oxalic acid was the most important final product. It presented a large persistence in $\mathrm{AO}-\mathrm{H}_{2} \mathrm{O}_{2}$ and $\mathrm{EF}$, but disappeared rapidly in PEF due to the quick photolysis of its $\mathrm{Fe}(\mathrm{III})$ complexes that explains the superior oxidation power of this EAOP.

Acknowledgments Financial support from MINECO (Ministerio de Economia y Competitividad, Spain) under project CTQ2013-48897-C2-1-R, co-financed with FEDER funds, and the Ph.D. fellowship awarded to N. Flores by SENESCYT (Secretaría Nacional de Educación Superior, Ciencia, Tecnología e Innovación, Ecuador) are acknowledged.

\section{References}

Assumpção MHMT, Moraes A, De Souza RFB, Reis RM, Rocha RS, Gaubeur I, Calegaro ML, Hammer P, Lanza MRV, Santos MC (2013) Degradation of dipyrone via advanced oxidation processes using a cerium nanostructured electrocatalyst material, Appl Catal AGen 462-463:256-261.

Borràs N, Oliver R, Arias C, Brillas E (2010) Degradation of atrazine by electrochemical advanced oxidation processes using a boron-doped diamond anode. J Phys Chem A 114(24):6613-6621.

Boye B, Dieng MM, Brillas E (2003) Electrochemical degradation of 2,4,5-trichlorophenoxyacetic acid in aqueous medium by peroxi-coagulation. Effect of $\mathrm{pH}$ and UV light. Electrochim Acta 48(7):781-790. 
Brillas E, Martínez-Huitle CA (2015) Decontamination of wastewaters containing synthetic organic dyes by electrochemical methods. An updated review. Appl Catal B-Environ 166-167:603643.

Cavalcanti EB, Garcia-Segura S, Centellas F, Brillas E (2013) Electrochemical incineration of omeprazole in neutral aqueous medium using a platinum or boron-doped diamond. Degradation kinetics and oxidation products. Water Res 47(5):1803-1815.

Chatzisymeon E, Dimou A, Mantzavinos D, Katsaounis A (2009) Electrochemical oxidation of model compounds and olive mill wastewater over DSA electrodes: 1 . The case of $\mathrm{Ti} / \mathrm{IrO} \mathrm{I}_{2}$ anode. J Hazard Mater 167(1-3):268-274.

Ciríaco L, Anjo C, Correia J, Pacheco MJ, Lopes A (2009) Electrochemical degradation of ibuprofen on $\mathrm{Ti} / \mathrm{Pt} / \mathrm{PbO}_{2}$ and $\mathrm{Si} / \mathrm{BDD}$ electrodes. Electrochim Acta 54(5):1464-1472.

Cruz-González K, Torres-López O, García-León A, Brillas E, Hernández-Ramírez A, PeraltaHernández JM (2012) Optimization of electro-Fenton/BDD process for decolorization of a model azo dye wastewater by means of response surface methodology. Desalination 286:6368.

Cruz-González K, Torres-López O, García-León A, Guzmán-Mar JL, Reyes LH, HernándezRamírez A, Peralta-Hernández JM (2010) Determination of optimum operating parameters for Acid Yellow 36 decolorization by electro-Fenton process using BDD cathode. Chem Eng J 160(1):199-206.

Deeb AA, Fayyad MK, Alawi MA (2012) Separation of polyphenols from Jordanian olive oil mill wastewater. Cromatogr Res Int Article ID 812127, 8 pp.

Di Gioia D, Bertin L, Fava F, Marchetti L (2001) Biodegradation of hydroxylated and methoxylated benzoic, phenylacetic and phenylpropenoic acids present in olive mill wastewaters by two bacterial strains. Res Microbiol 152(1):83-93. 
Dirany A, Sirés I, Oturan N, Özcan A, Oturan MA (2012) Electrochemical treatment of the antibiotic sulfachloropyridazine: kinetics, reaction pathways, and toxicity evolution. Environ Sci Technol 46(7):4074-4082.

El-Ghenymy A, Rodríguez RM, Brillas E, Oturan N, Oturan MA (2014) Electro-Fenton degradation of the antibiotic sulfanilamide with Pt/carbon-felt and BDD/carbon-felt cells. Kinetics, reaction intermediates, and toxicity assessment. Environ Sci Pollut Res 21(14):8368-8378.

Florenza X, Solano AMS, Centellas F, Martínez-Huitle CA, Brillas E, Garcia-Segura S (2014) Degradation of the azo dye Acid Red 1 by anodic oxidation and indirect electrochemical processes based on Fenton's reaction chemistry. Relationship between decolorization, mineralization and products. Electrochim Acta 142:276-288.

Guinea E, Brillas E, Centellas F, Cañizares P, Rodrigo MA, Saez C (2009) Oxidation of enrofloxacin with conductive-diamond electrochemical oxidation, ozonation and Fenton oxidation. A comparison. Water Res 43(8):2131-2138.

Hakkim FL, Miura M, Matsuda N, Alharassi AS, Guillemin G, Yamauchi M, Arivazhagan G, Song $\mathrm{H}$ (2014) An in vitro evidence for caffeic acid, rosmarinic acid and trans-cinnamic acid as a skin protectant against $\gamma$-radiation. Int J Low Rad 9(4):305-316.

Hojati M, Modarres-Sanavy SAM, Enferadi ST, Majdi M, Ghanati F, Farzadfar S (2015) Differential deployment of parthenolide and phenylpropanoids in feverfew plants subjected to divalent heavy metals and trans-cinnamic acid. Plant Soil DOI:10.1007/s11104-015-2677-0.

Khataee A, Akbarpour A, Vahi B (2014) Photoassisted electrochemical degradation of an azo dye using $\mathrm{Ti} / \mathrm{RuO}_{2}$ anode and carbon nanotubes containing gas-diffusion cathode. J Taiwan Inst Chem Eng 45(3):930-936.

Khataee A, Khataee A, Fathinia M, Vahid B, Joo SW (2013) Kinetic modeling of photoassistedelectrochemical process for degradation of an azo dye using boron-doped diamond anode and cathode with carbon nanotubes. J Ind Eng Chem 19(6):1890-1894. 
Kontos SS, Koutsoukos PG, Paraskeva CA (2014) Removal and recovery of phenolic compounds from olive mill wastewater by cooling crystallization. Chem Eng J 251:319-328.

Lafont F, Garcia IM, Aramendia MA, Marinas JM, Urbano FJ, Fernandez JM, Marti V (2001) Automated on-line solid-phase extraction and HPLC-mass spectrometry for rapid determination of phenolic compounds found in olive mill wastewaters. Adv Mass Spectrom 15:875-876.

Letizia CS, Cocchiara J, Lapczynski A, Lalko J, Api AM (2005) Fragrance material review on cinnamic acid. Food Chem Toxicol 43(6):925-943.

Lopes RJG, Quinta-Ferreira RM (2010) Assessment of CFD-VOF method for trickle-bed reactor modeling in the catalytic wet oxidation of phenolic wastewater. Ind Eng Chem Res 49(6):2638-2648.

Lopes RJG, Silva AMT, Quinta-Ferreira RM (2007) Screening of catalysts and effect of temperature for kinetic degradation studies of aromatic compounds during wet oxidation. Appl Catal B-Environ 73(1-2):193-202.

Marselli B, Garcia-Gomez J, Michaud PA, Rodrigo MA, Comninellis C (2003) Electrogeneration of hydroxyl radicals on boron-doped diamond electrodes. J Electrochem Soc 150(3):D79D83.

Martínez-Huitle CA, Ferro S (2006) Electrochemical oxidation of organic pollutants for the wastewater treatment: direct and indirect processes. Chem Soc Rev 35(12):1324-1340.

Moreira FC, Garcia-Segura S, Vilar VJP, Boaventura RAR, E. Brillas E (2013) Decolorization and mineralization of Sunset Yellow FCF azo dye by anodic oxidation, electro-Fenton, UVA photoelectro-Fenton and solar photoelectro-Fenton processes. Appl Catal B-Environ 142143:877-890.

Panizza M, Cerisola G (2009) Direct and mediated anodic oxidation of organic pollutants. Chem Rev 109(12):6541-6569. 
Rodrigo MA, Cañizares P, Sánchez-Carretero A, Sáez C (2010) Use of conductive-diamond electrochemical oxidation for wastewater treatment. Catal Today 151(1-2):173-177.

Ruiz EJ, Hernández-Ramírez A, Peralta-Hernández JM, Arias C, Brillas E (2011) Application of solar photoelectro-Fenton technology to azo dyes mineralization: Effect of current density, $\mathrm{Fe}^{2+}$ and dye concentrations. Chem Eng J 171(2):385-392.

Sanchez I, Stüber F, Fabregat A, Font J, Fortuny A, Bengoa C (2012) Degradation of model olive mill contaminants of OMW catalysed by zero-valent iron enhanced with a chelant. J Hazard Mater 199-200:328-335.

Sirés I, Brillas E (2012) Remediation of water pollution caused by pharmaceutical residues based on electrochemical separation and degradation technologies: a review. Environ Int 40:212229.

Sirés I, Brillas E, Oturan MA, Rodrigo MA, Panizza M (2014) Electrochemical advanced oxidation processes: today and tomorrow. A review. Environ Sci Pollut Res 21(14):8336-8367.

Thiam A, Sirés I, Centellas F, Cabot PL, Brillas E (2015a) Decolorization and mineralization of Allura Red AC azo dye by solar photoelectro-Fenton: Identification of intermediates. Chemosphere 136:1-8.

Thiam A, Sirés I, Garrido JA, Rodríguez RM, Brillas E (2015b) Decolorization and mineralization of Allura Red AC aqueous solutions by electrochemical advanced oxidation processes, J Hazard Mater 290:34-42.

Thiam A, Zhou M, Brillas E, Sirés I (2014) Two-step mineralization of Tartrazine solutions: Study of parameters and by-products during the coupling of electrocoagulation with electrochemical advanced oxidation processes. Appl Catal B-Environ 150-151:116-125.

Vasudevan S, Oturan MA (2014) Electrochemistry: As cause and cure in water pollution-an overview. Environ Chem Lett 12(1):97-108. 
Vatanpour V, Daneshvar N, Rasoulifard MH (2009) Electro-Fenton degradation of synthetic dye mixture: influence of intermediates. J Environ Eng Manage 19(1):277-282.

Wang A, Qu J, Liu H, Ru R (2008) Mineralization of an azo dye Acid Red 14 by photoelectroFenton process using an activated carbon fiber cathode. Appl Catal B-Environ 84(3-4):393399.

Yahya MS, Oturan N, El Kacemi K, El Karbane M, Aravindakumar CT, Oturan MA (2014) Oxidative degradation study on antimicrobial agent ciprofloxacin by electro-Fenton process: Kinetics and oxidation products. Chemosphere 117:447-454.

Zeni ALB, de Albuquerque CAC, Goncalves F, Latini A, Tasca CI, Podesta R, Pagliosa CM, Duarte FS, de Lima TCM, Maraschin M (2013) Phytochemical profile, toxicity and antioxidant activity of Aloysia gratissima (Verbenaceae). Quim Nova 36(1):69-73. 


\section{Figure captions}

Fig. 1 trans-Cinnamic acid content vs. electrolysis time for the degradation of $100 \mathrm{~mL}$ of a 0.926 $\mathrm{mM}$ substrate solution in $0.05 \mathrm{M} \mathrm{Na}_{2} \mathrm{SO}_{4}$ at $\mathrm{pH} 3.0$ and $25^{\circ} \mathrm{C}$ using a BDD/air-diffusion cell of 3 $\mathrm{cm}^{2}$ electrode area at $33.3 \mathrm{~mA} \mathrm{~cm}$. In (a), anodic oxidation with electrogenerated $\mathrm{H}_{2} \mathrm{O}_{2}(\mathrm{AO}-$ $\mathrm{H}_{2} \mathrm{O}_{2}$ ). In (b), ( $\left.\boldsymbol{\square}\right)$ electro-Fenton (EF) with $0.50 \mathrm{mM} \mathrm{Fe}^{2+}$ and ( $\boldsymbol{\Delta}$ ) photoelectro-Fenton (PEF) with $0.50 \mathrm{mM} \mathrm{Fe}{ }^{2+}$ using a $6 \mathrm{~W}$ UVA light. The pseudo-first-order kinetic analysis for the transcinnamic acid concentration abatement is shown in the inset panels

Fig. 2 (a) TOC removal and (b) variation of mineralization current efficiency with electrolysis time under the conditions of Fig. 1. Method: $(\boldsymbol{O}) \mathrm{AO}-\mathrm{H}_{2} \mathrm{O}_{2},(\boldsymbol{\square}) \mathrm{EF}$ and $(\boldsymbol{\Delta}) \mathrm{PEF}$

Fig. 3 Effect of current density on TOC decay vs. electrolysis time for the treatment of $100 \mathrm{~mL}$ of a $0.926 \mathrm{mM}$ trans-cinnamic acid solution in $0.05 \mathrm{M} \mathrm{Na}_{2} \mathrm{SO}_{4}$ at $\mathrm{pH} 3.0$ and $25^{\circ} \mathrm{C}$ using a BDD/airdiffusion cell. Method: (a) AO- $\mathrm{H}_{2} \mathrm{O}_{2}$, (b) EF and (c) PEF. Applied current density: (O) $16.7 \mathrm{~mA}$ $\mathrm{cm}^{-2},(\mathbf{\Delta}) 33.3 \mathrm{~mA} \mathrm{~cm}^{-2},(\diamond) 66.7 \mathrm{~mA} \mathrm{~cm}^{-2}$ and $(\boldsymbol{\nabla}) 100 \mathrm{~mA} \mathrm{~cm}^{-2}$

Fig. 4 Mineralization current efficiency vs. electrolysis time for the trials of Fig. 3

Fig. 5 Effect of trans-cinnamic acid concentration on TOC removal with electrolysis time for the degradation of $100 \mathrm{~mL}$ of solutions of this substrate in $0.05 \mathrm{M} \mathrm{Na}_{2} \mathrm{SO}_{4}$ at $\mathrm{pH} 3.0$ using a BDD/airdiffusion cell at $33.3 \mathrm{~mA} \mathrm{~cm}{ }^{-2}$ and $25^{\circ} \mathrm{C}$. Method: (a) AO- $\mathrm{H}_{2} \mathrm{O}_{2}$, (b) EF and (c) PEF. Content of trans-cinnamic acid: $(\bigcirc) 0.185 \mathrm{mM},(\diamond) 0.463 \mathrm{mM},(\boldsymbol{\Delta}) 0.926 \mathrm{mM}$ and $(\boldsymbol{\square}) 1.852 \mathrm{mM}$

Fig. 6 Variation of mineralization current efficiency with electrolysis time for the experiments given in Fig. 5

Fig. 7 Time-course of the concentration of oxalic acid (10) detected during the treatments shown in Fig. 2. Method: $(\mathbf{O}) \mathrm{AO}-\mathrm{H}_{2} \mathrm{O}_{2},(\mathbf{\square}) \mathrm{EF}$ and $(\boldsymbol{\Delta}) \mathrm{PEF}$ 
Fig. 8 Route for trans-cinnamic acid mineralization by $\mathrm{AO}-\mathrm{H}_{2} \mathrm{O}_{2}$, EF and PEF using a BDD/air-

1

2

3

4

5

6

7

8

9

10

11

12

13

14

15

16

17

18

19

20

21

22

23

24

25

26

27

28

29

30

31

32

33

34

35

36

37

38

39

40

41

42

43

44

45

46

47

48

49

50

51

52

53

54

55

56

57

58

59

60

61

62

63

64

65

diffusion cell. The species ${ }^{\circ} \mathrm{OH}$ in the sequence of aromatics represents their oxidation by $\mathrm{BDD}\left({ }^{\bullet} \mathrm{OH}\right)$ at the $\mathrm{BDD}$ surface and/or ${ }^{\bullet} \mathrm{OH}$ from Fenton's reaction in the bulk 

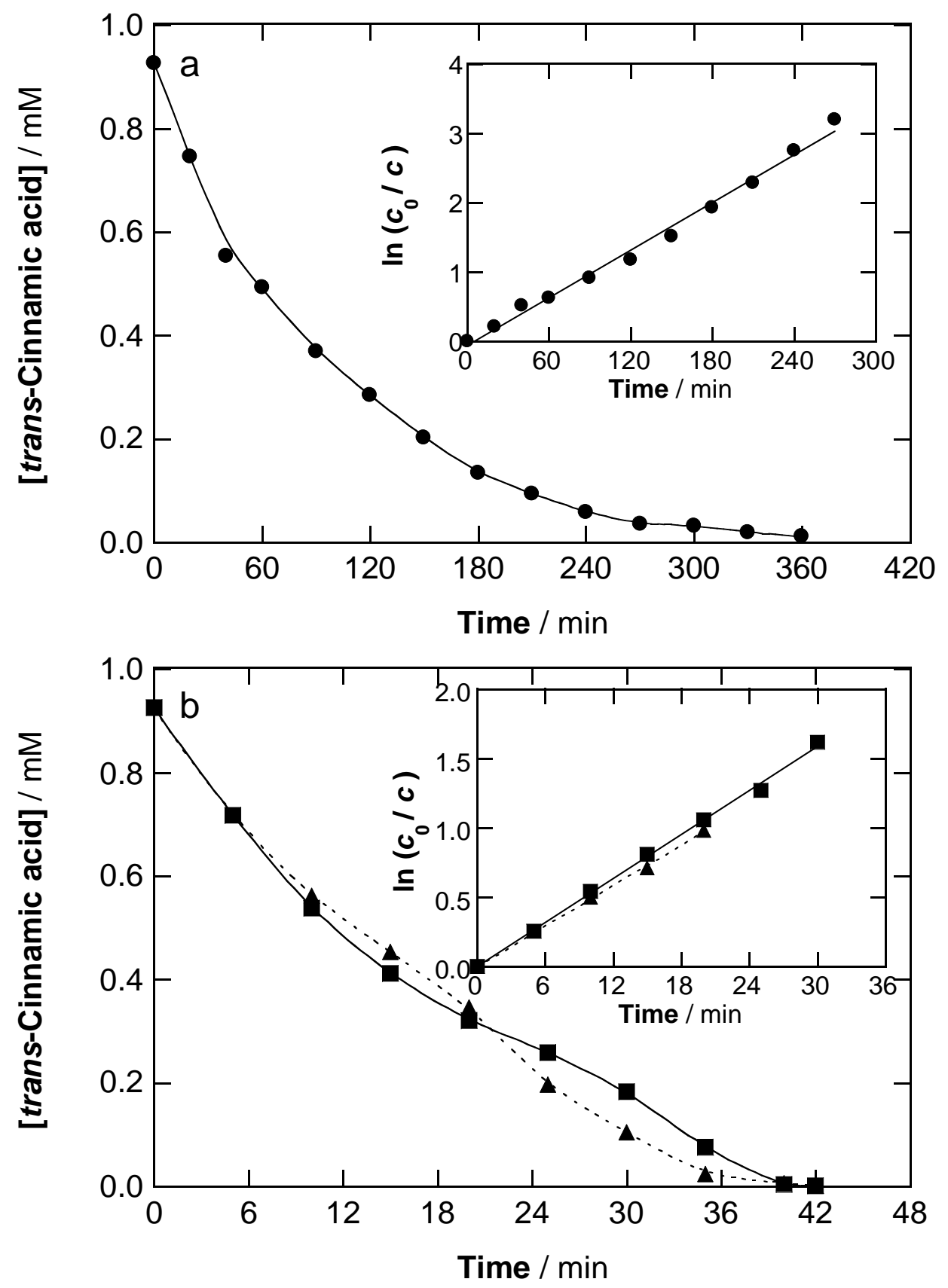

Fig. 1 


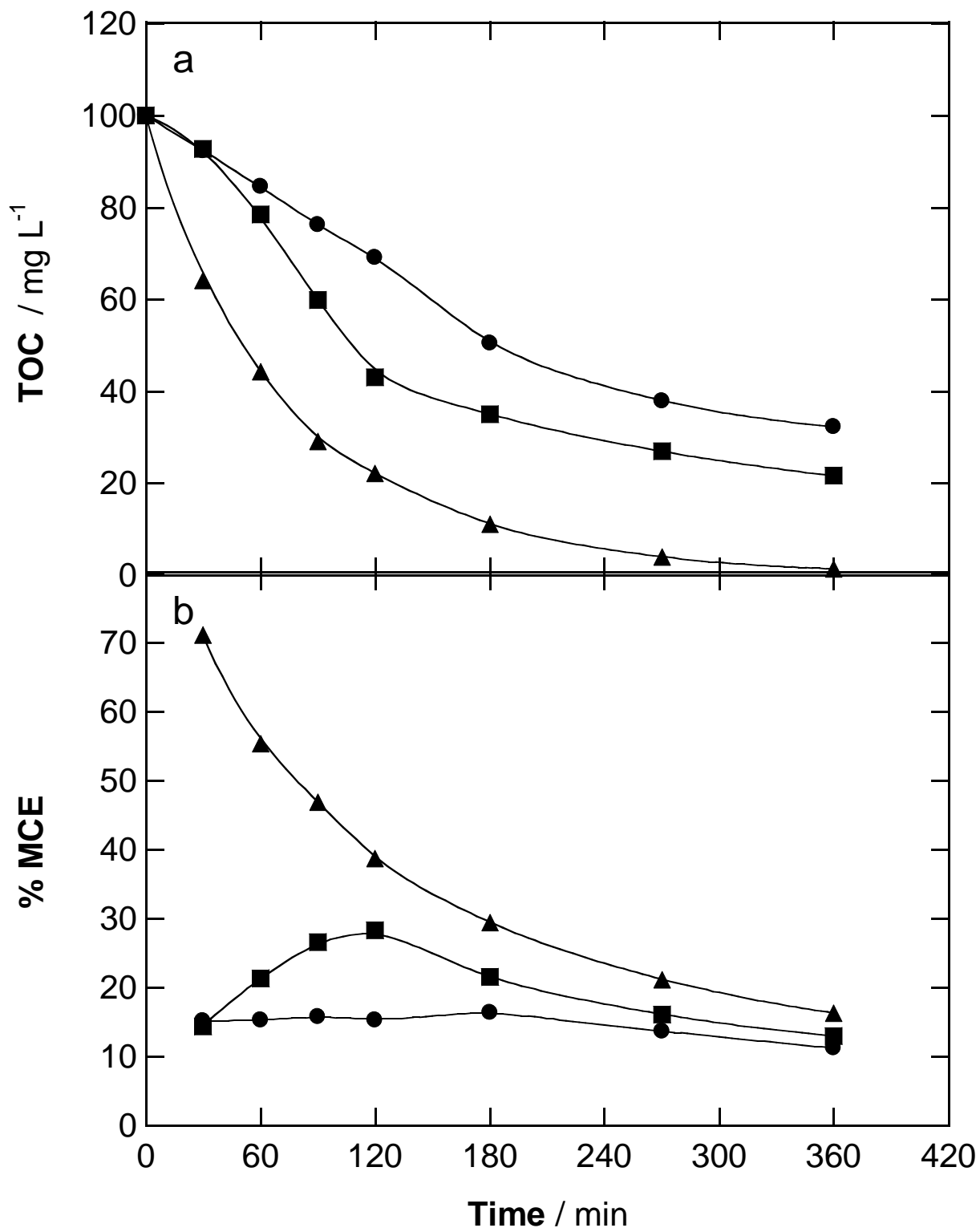

Fig. 2 


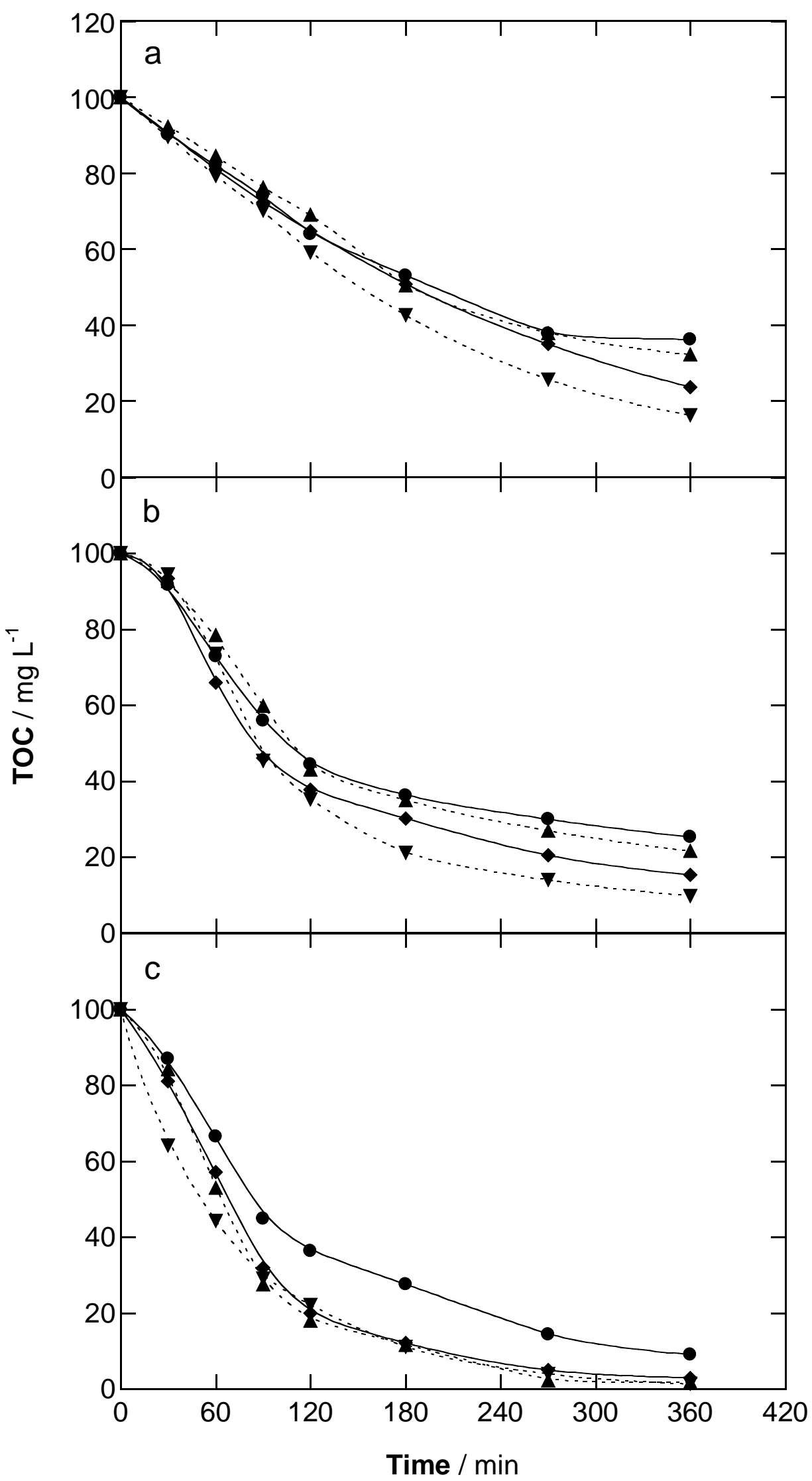

Fig. 3 


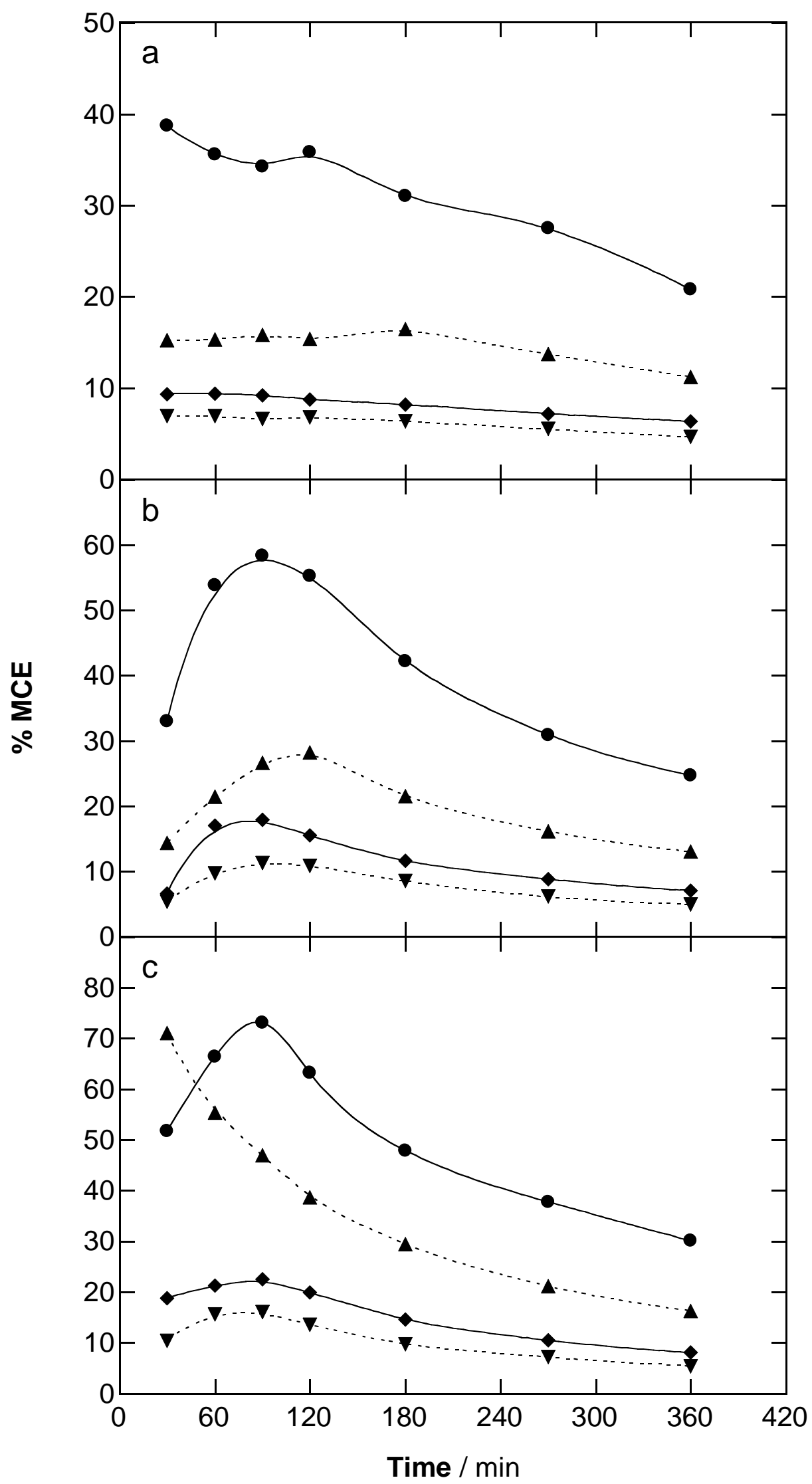

Fig. 4 


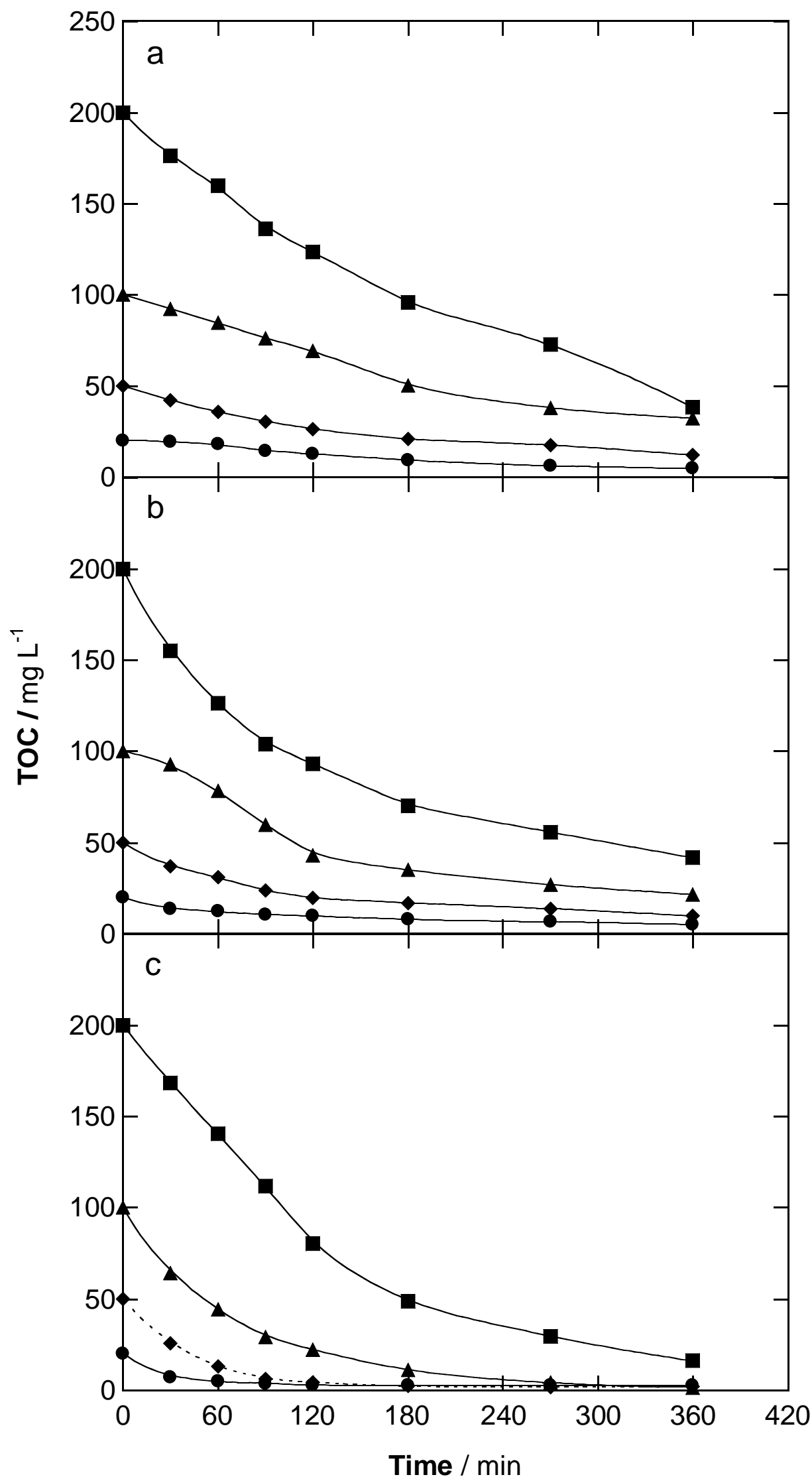

Fig. 5 


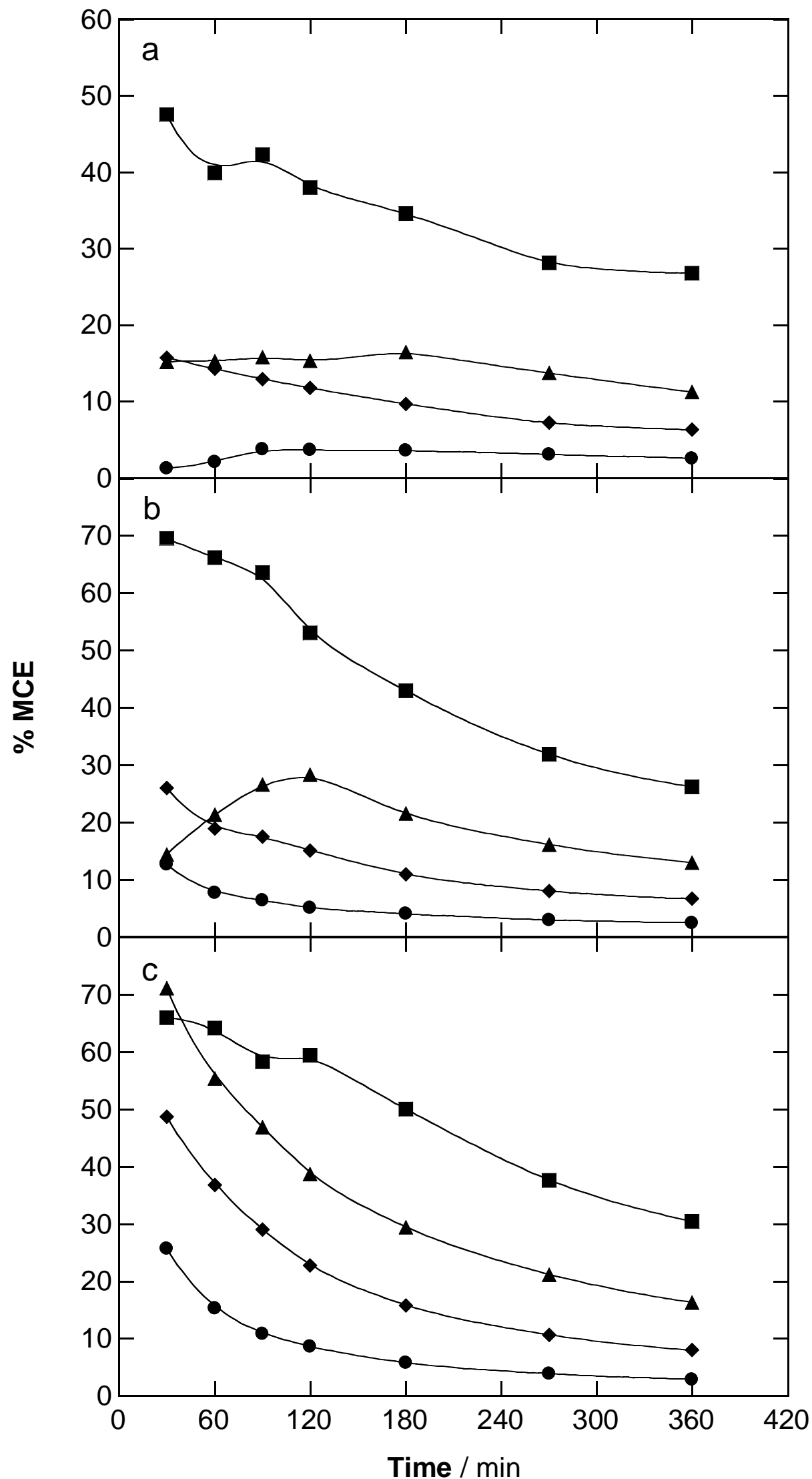

Fig. 6 


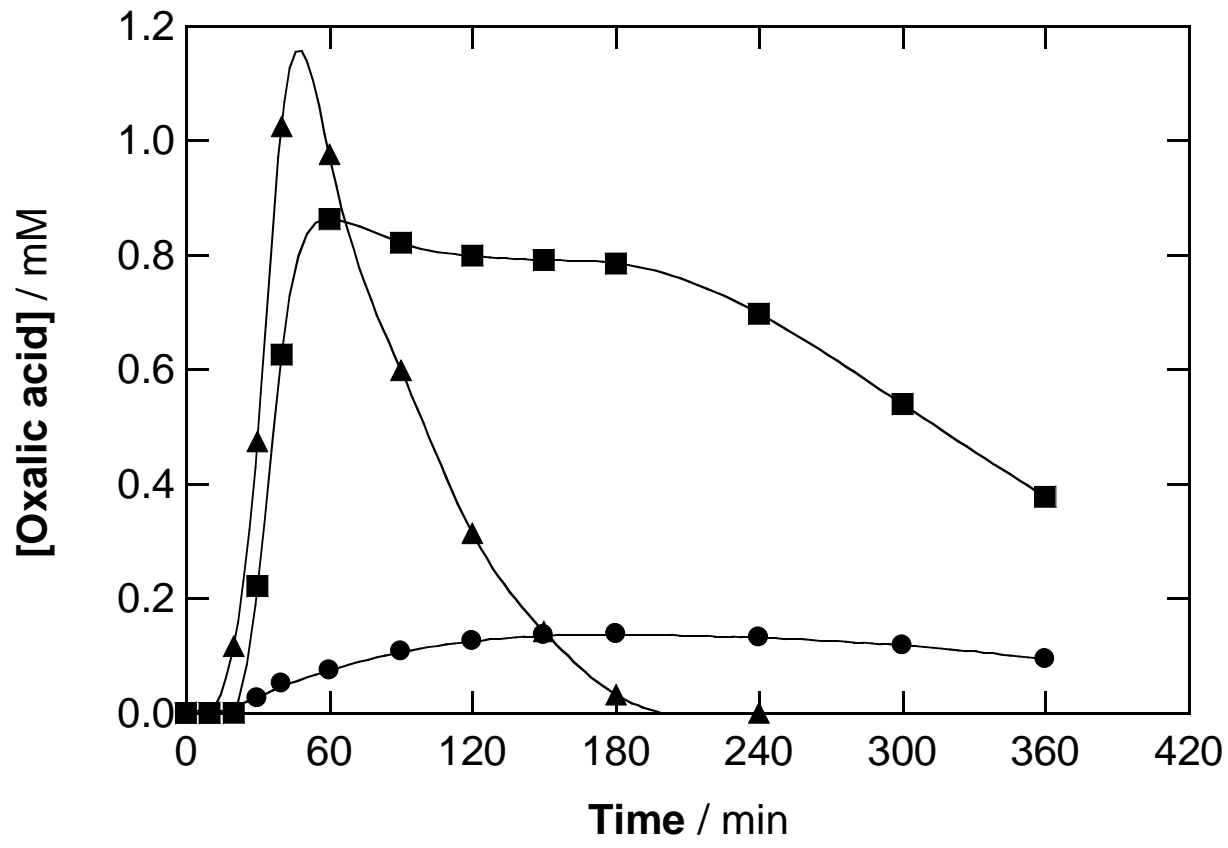

Fig. 7 

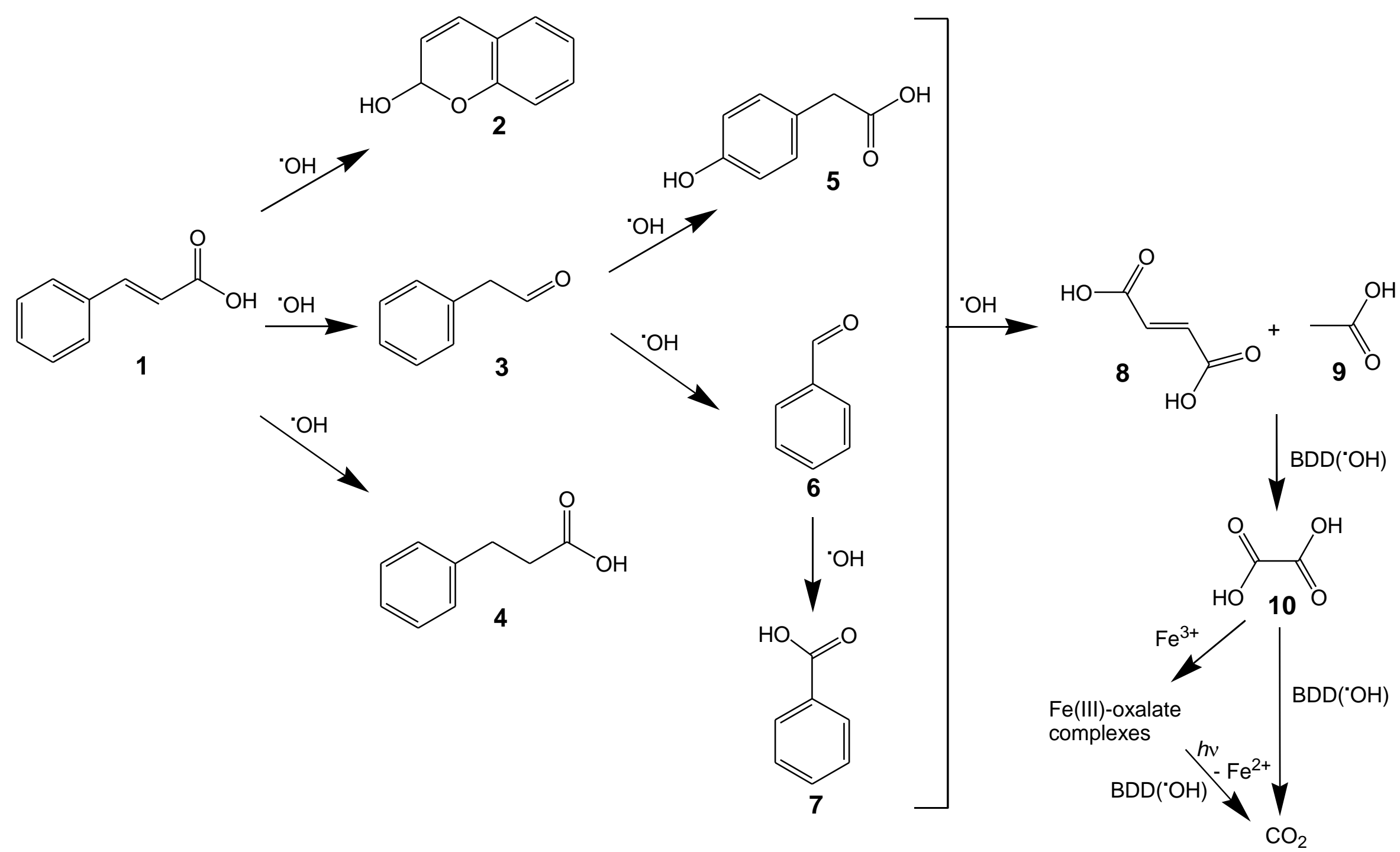

Fig. 8 
Table 1 Products identified by GC-MS during the electrolysis of $100 \mathrm{~mL}$ of a $0.926 \mathrm{mM}$ transcinnamic acid solution in $0.05 \mathrm{M} \mathrm{Na}_{2} \mathrm{SO}_{4}$ at $\mathrm{pH} 3.0$ and $25^{\circ} \mathrm{C}$ by $\mathrm{AO}-\mathrm{H}_{2} \mathrm{O}_{2}$ using a stirred BDD/airdiffusion cell at $33.3 \mathrm{~mA} \mathrm{~cm}^{-2}$.

\begin{tabular}{|c|c|c|c|c|c|}
\hline Number & Name & Molecular structure & $t_{\mathrm{r}}(\min )$ & $m / z$ & $\begin{array}{l}\text { Electrolysis } \\
\text { time (min) }\end{array}$ \\
\hline 1 & trans-Cinnamic acid & & $\begin{array}{l}26.2^{\mathrm{a}} \\
42.2^{\mathrm{b}}\end{array}$ & $\begin{array}{c}148\left(\mathrm{M}^{+}\right) \\
147,131 \\
103\end{array}$ & $\begin{array}{l}30,90 \\
30,90\end{array}$ \\
\hline 2 & $\begin{array}{l}\text { 2H-1-Benzopyran-2- } \\
\text { one or Coumarin }\end{array}$ & & $35.7^{\mathrm{b}}$ & $\begin{array}{c}146\left(\mathrm{M}^{+}\right) \\
118,90,63\end{array}$ & 30,90 \\
\hline 3 & Benzeneacetaldehyde & & $19.9^{\mathrm{b}}$ & $\begin{array}{c}120\left(\mathrm{M}^{+}\right) \\
91,65\end{array}$ & 30,90 \\
\hline 4 & 3-Phenylpropanoic acid & & $\begin{array}{l}20.5^{\mathrm{a}} \\
31.3^{\mathrm{b}}\end{array}$ & $\begin{array}{c}150\left(\mathrm{M}^{+}\right) \\
135,107,77\end{array}$ & $\begin{array}{l}30,90 \\
30,90\end{array}$ \\
\hline 5 & $\begin{array}{l}\text { 4-Hydroxyphenylacetic } \\
\text { acid }\end{array}$ & 11 & $37.5^{\mathrm{b}}$ & $\begin{array}{c}152\left(\mathrm{M}^{+}\right) \\
151,137, \\
123,109,81\end{array}$ & 30,90 \\
\hline 6 & Benzaldehyde & & $17.1^{\mathrm{b}}$ & $\begin{array}{c}106\left(\mathrm{M}^{+}\right) \\
105,77\end{array}$ & 30 \\
\hline 7 & Benzoic acid & & $35.3^{\mathrm{b}}$ & $\begin{array}{l}122\left(\mathrm{M}^{+}\right), \\
105,77,51\end{array}$ & 30,90 \\
\hline 10 & Oxalic acid & $\mathrm{COOH}-\mathrm{COOH}$ & $24.9^{\mathrm{b}}$ & $\begin{array}{c}89\left((\mathrm{M}-\mathrm{H})^{-}\right), \\
71,50\end{array}$ & 90 \\
\hline
\end{tabular}

Retention times for: ${ }^{\mathrm{a}}$ non-polar Agilent J\&W HP-5ms and ${ }^{\mathrm{b}}$ polar HP INNOWax columns. 